\section{Dr. Carl C. Heimburger}

Dr. Carl Heimburger is the Dean of Canadian forest tree breeders. He began by making artificial poplar hybrids in the early 1930's and is by no means finished yet. This year (1969) he is busy on several papers including a report on a recent visit to tree breeding establishments in Japan.

However, Carl's interest in plant breeding had begun long before. The Heimburger family grew up in St. Petersburg, Russia under the Tsars. Carl just finished high school in time to escape from the Bolshevik Revolution. The family reunited in Denmark, each member with his most prized possessions. Carl had a package of hybrid seeds!

In Denmark, he attended the Royal Veterinary and Agricultural College and obtained his master's degree in forestry. In 1925 he emigrated to Canada, and worked for the old Wagagamack Pulp and $\mathrm{Pa}$ per Company. Feeling that a degree from a Canadian school would be helpful in his new country, Carl enrolled in the Faculty of Forestry, University of Toronto, and in two years obtained his second bachelor's degree in forestry. After graduation, he began his research career by working with the Ontario Department of Lands and Forests. Perceiving that a doctorate degree was essential to a research man, Carl left his job to take further graduate work at Cornell University. His Ph.D. thesis on the forest types of the Adirondacks is still highly regarded and widely quoted. However, he had the bad luck to graduate in the middle of the great depression (1933), and the only employment he could obtain was with a lumber company in British Columbia. However, the work was not research so he left to take a job at the Petawawa Forest Experiment Station under the old Dominion Forest Service at $\$ 50$ per month. (At this time students were working for nothing to gain experience, and graduate foresters were paid as low as $\$ 37.50$ per month). His official job was to set up and describe the forest types at Petawawa, but unofficially he spent his spare time in plant breeding. His interest centered on poppies, and "Heimie's Garden" at Petawawa was a show place of gay colour. But he did not forget the trees, and working with detached branches in old beer bottles, he produced the first artificial poplar hybrids in Canada.

As time went on, Carl spent more and more time on tree breeding. In 1937 he addressed a seminar at the National Research Council Laboratories on the need for a tree breeding program in Canada, and by 1939 he had interested enough people to start an official tree breeding program under the joint auspices of the National Research Council of Canada and the Dominion Forest Service. This ambitious program was severely crippled by the Second World War. In spite of that, since the first group began tree breeding work at Petawawa, there has always been a tree breeding program there. Furthermore, from this nucleus has developed the tree breeding program of the Canada Department of Fisheries and Forestry, which now covers most Canadian provinces and is still centered at Petawawa.

After the War, Carl initiated a tree breeding program at the Southern Research Station, Maple, under the Ontario Department of Lands and Forests. $\mathrm{He}$ continued to work there until his recent retirement. His principal efforts were directed toward producing a white pine resistant to the blister rust and to the white pine weevil. He collected materials from all over the world and developed a highly effective method for artificial inoculation in the seedling stage which saved the expense of transplanting susceptible seedlings. He also continued his work on developing a poplar with high quality wood like aspen, yet which could be propagated by stem cuttings like a cottonwood. He always had faith in poplar, and had enough vision to see that breeding should center around those genera with rapid growth, possibilities for genetic improvement, and capacity for easy propagation.

Carl had no use for the red tape that seems to go with government organizations. This often put him at odds with administrators. Carl was always anxious to get on with his research and resented the time spent in filling out forms. His working time seldom ended before midnight and usually included weekends. Yet he was always ready to take time from his own research to help another person with advice or materials.

His contribution to scientific research was recognized in 1953 when he was made a Fellow of the Royal Society of Canada.

Carl was years ahead of his time in much of his thinking. It was not only in connection with forestry that he foresaw future developments. As early as 1935 he was talking seriously of rocket trips to the moon; this at a time when the only rocket most people had heard of was the kind that took a firecracker into the air, and a trip to the moon was the ultimate in impractical ideas.

Carl has always had remarkably keen powers of observation. He could pick out one or two hybrid seedlings in a nursery from among the thousands of individuals of the pure species. He often spotted hybrids and rare species from the car as he drove along the road.

Even in retirement, $\mathrm{Carl}$ is active in the field of tree breeding. He has enough data for several more papers and is one of the editors for Silvae Genetica. At the same time he can look at the present tree breeding activity in Canada and take great satisfaction from the part that he played in its development.

J. L. Farrar. 